\title{
STUDENTS' PREFERENCES ON ONLINE LEARNING IN THE NEW NORMAL PERIOD OF THE COVID-19 PANDEMIC
}

\author{
Roswani Siregar ${ }^{1}$, Syahron Lubis ${ }^{2}$, Risnawaty ${ }^{3}$, Andri Ramadhan ${ }^{4}$ \\ 1,4 Universitas Al-Azhar, Medan, Indonesia \\ ${ }^{2}$ Universitas Sumatera Utara, Medan, Indonesia \\ ${ }^{3}$ Universitas Muslim Nusantara Al-Washliyah, Medan, Indonesia \\ E-mail:roses_air@yahoo.com
}

Received: 2021-11-07

Accepted: 2021-11-27

\begin{abstract}
This study aims to investigate the students' preferences on online learning systems in the new normal period of the Covid-19 pandemic. This study used descriptive qualitative research and adopted a survey method to collect the quantitative data from 95 students in two universities related to students experiences on learning classes, devices and mediums, learning environment, material format and comprehension, resources, time management, peers and lecturer communication, and limitation and benefit of online learning. This study also highlights the lecturer's effort to overcome the general obstacles amid the online learning process. The use of various formats of learning materials is effective for students who face poor internet access in remote areas. Moreover, feedback is vital for both lecturer and students in maintaining the engagement of communication. Finally, the results of this study provide essential information in understanding the effectiveness of online learning particularly amid the new normal period from the university setting.
\end{abstract}

Keywords: online learning, experiences, student preference, obstacles, medium

\section{Introduction}

Since the outbreak of the Covid-19 in March 2020 in Indonesia, social distancing and lockdowns have changed the way of working and learning. The government enacted rules to carry out activities from home nationwide through the Circular Letter of the Minister of Education and Culture Number 36962/MPK.A/HK/2020 dated March 17, 2020, regarding Online Learning and Working from Home to Prevent the Spread of Covid-19. The Point 4a of the decree explains the application of online learning at home for students. Point $4 b$ describes the teaching and learning process or lectures from home through video conferencing, digital documents, and other online facilities. (Minister of Education and Culture of the Republic of Indonesia, 2020).

Students and faculties experience stress that obviously by a dramatic decline in learning satisfaction. The students are studying at home while learning activities in class are prompt to online. The learning system shifted from face-to-face into a distance learning (Hamid et al., 2020). The massive distance learning enforces throughout Indonesia, from early childhood education to higher education and other institutions. Since then, online learning has become the only learning system during the pandemic. However, the online learning system is like a coin that offers its advantages and disadvantages. The main advantage is that education is continuing even though it is not possible to meet face-to-face. Another 
advantage is the reduction in travel costs, time, and space. On the other hand, its drawbacks are the lack of physical interaction and fatigue. According to several studies, the obstacles of online learning implementation are the limitations of technological devices and users' technology literacy. These limitations reduce the communication and learning experiences that affect the students' satisfaction with ongoing learning (Atqia et al., 2021; Churiyah et al., 2020; Syahruddin et al., 2021).

The problems regarding online learning above were found in several areas. The objective of this study is to describe the conditions of online learning carried out in Medan, North Sumatra through the learning experiences of students who take English courses in two universities. The main problem observed on the surface is that students are less motivated to interact in the online learning system. The fact indicates that most students turn off video conferencing face-to-face online, in addition to not providing comments or questions about the topics discussed. On the other hand, the attendance rate is relatively low. Most students are not present during the course schedule via video conferencing but are present at other times to access learning materials. This causes a lack of input that can be used by lecturers to improve the quality of learning.

Based on the description above, this article aims to present the students' preferences for online learning since the new normal, March 2021. These preferences reflected the problems in connection with the lack of interaction in teaching and learning, the lack of attendance, the preferred learning media, and the desired learning system in the future. The results of this study enrich the references in understanding the effectiveness of online learning in Indonesia.

\section{Literature Review}

\subsection{Online Learning during the Covid-19 Pandemic}

The outbreak of COVID-19 has changed many ways of doing human activities since the beginning of 2020. In Indonesia, the government has also established a social distancing policy to break the chain of transmission of the Covid-19 virus and limit human interaction. This policy keeps the social distancing, carries out all activities at home, includes educational activities online. The Covid-19 pandemic has also stimulated global educational institutions to find out the effective way to undergo education activities in a short time (Muthuprasad et al., 2021). Educational institutions in Indonesia are no exception to support social distancing and switch from face-to-face learning to online teaching and learning activities.

Online learning is a new thing for most students. Although some universities already have e-learning portals, distance learning has never used by regular students before the pandemic. Thus, most of the universities were not ready. The available learning and meeting applications such as Zoom, Google Meet, WhatsApp are commonly applied to assist in the implementation of online learning and means of communication between lecturers and students (Rizaldi \& Fatimah, 2020). Many universities use social media to facilitate teaching and learning activities and online learning-based learning management systems (LMS) (Mulyono et al., 2021).

\subsection{Response to Online Learning Implementation}

During the covid-19 pandemic, students' experiences with online learning are varied. The positive impact of online learning is the growth of students' independence in learning. Thus, the students' satisfaction was crucial. Five components suggested becoming pillars of 
online teaching are effectiveness, accessibility, cost-effectiveness, student satisfaction, and faculty satisfaction (Violante \& Vezzetti, 2015).

Students' responses to online learning have been reported in recent studies. Most students are well-prepared to carry out online learning programs with the support of adequate internet network infrastructure. In several studies, students prefer online lectures rather than offline and mixed interaction models between face-to-face and non-face-to-face. Most of the students also feel they understand the material provided and are satisfied with the online class (Redaputri et al., 2021). However, a different response was suggested by (Utami, 2021) that most students prefer face-to-face learning.

The reasons are also similar to other findings. Most students are not satisfied with how the lecturers teach using e-learning. Lecturers' performance and students' experience in using e-learning platforms, and accessibility to e-learning websites have been shown to have a significant impact on students' satisfaction. The better and skilled the lecturers in using elearning, the higher the student satisfaction in learning. Lecturer performance in e-learning is influenced by several factors, including the time-consuming production of e-learning materials that can interfere with the availability of technical support during e-learning implementation and various strategies to facilitate e-learning (Bani Hani et al., 2021).

\subsection{Online Learning Problems and User Readiness}

Distance learning, which is still new for students and lecturers, requires both technical and mental readiness. It affects the satisfaction of online learning users. The main obstacle faced by lecturers and students is the poor internet connection. It leads to delay in assignments submission and interruption during the class (Hutauruk \& Sidabutar, 2020). Similar to this argument, the difficulty of the internet network, limited quotas, unfamiliarity with the use of learning media, and a less supportive environment for conducting online learning are obstacles to the ineffectiveness of online learning (Arifin et al., 2021).

Many e-learning users question the effectiveness of online learning. Developing effective online learning programs and increasing the uptake of online learning should consider the barriers to online learning. One solution to these obstacles is to adopt an online LMS that is following the goals and learning needs of students. Although there has been an increase in the implementation of online learning globally, there are still some obstacles in countries (Thepwongsa et al., 2021).

Difficulties in adopting an LMS include financial and technological limitations, insufficient support and more time spent by lecturers to build online modules, suitable learning designs for students and lecturer needs, and the uncustomized LMS design (Barteit et al., 2020). Although online lecturers also have time flexibility on virtual classes that can be accessed anytime and anywhere, online learning becomes a new challenge for both. Students are required to play an active role in exploring the material prepared by the lecturer to make it easier to understand the material (Sadikin \& Hamidah, 2020). Other things to consider include the procedures implemented during online exams to minimize the possibility of cheating. Appropriate e-learning resources must be available to ensure the implementation of this major change. The ideal assessment was based on an optimal evaluation strategy. In addition, lecturers and universities must coordinate to estimate sufficient time for students to complete exam questions (Elzainy et al., 2020). 
Students' Preferences on Online Learning in The New Normal Period of The Covid-19 Pandemic, Roswani Siregar, Syahron Lubis, Risnawaty, Andri Ramadhan

\section{Research Method}

This study used descriptive qualitative research. The participants of this study were students of Al-Azhar University and the University of North Sumatra. The technique used to determine the participants is purposive sampling. The participants of this study are students of Economic Faculty and Engineering who are in semester 2 for academic year 2020/2021. The setting of this study is the online learning for English class conducted from March 2021 to August 2021.

A set of questionnaire that consisted of 28 items are distributed to 95 respondents. The questionnaire items are grouped into three categories, namely student preferences for online learning, learning medium and material formats, and advantages and limitations of online learning. Each items were assessed in Likert-type three-point scales namely, $A=$ Agree, $\mathrm{N}=$ Neutral, and $\mathrm{D}=$ Disagree. In addition, there are several questions with choices.

The students responses to those questions were collected in Google Form. Each description of the statement is prepared based on a review of the literature and the results of other studies to minimize researcher bias. In analyzing and summarizing perceptions, statements were graded on a three-point continuum scale. Frequency and percentage were calculated for each item to summarize the responses score. The students' preferences were analized based on the scores finding.

\section{Results and Discussion}

\subsection{Student Preference on Online Learning}

Learning English at Al-Azhar University and North Sumatra University from mid-March 2020 to September 2021 was conducted online. The students' preferences in online learning is presented in the following figures:

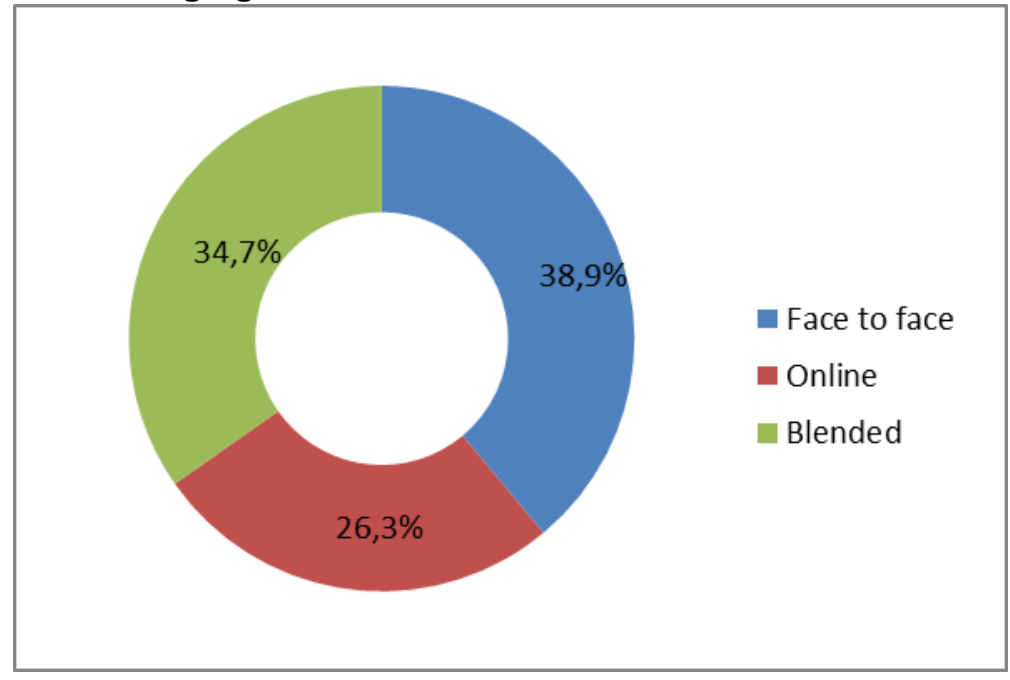

Figure 1. Preferred learning system

Based on data analysis in the current semester that was carried out from March to August 2021, it was identified that most of students preferred face-to-face learning system. It was shown Figure 1, where out of 95 students, 38,9\% of them prefer face to face learning system, $26,3 \%$ of students prefer online learning, and $34,7 \%$ of students prefer blended learning system. 


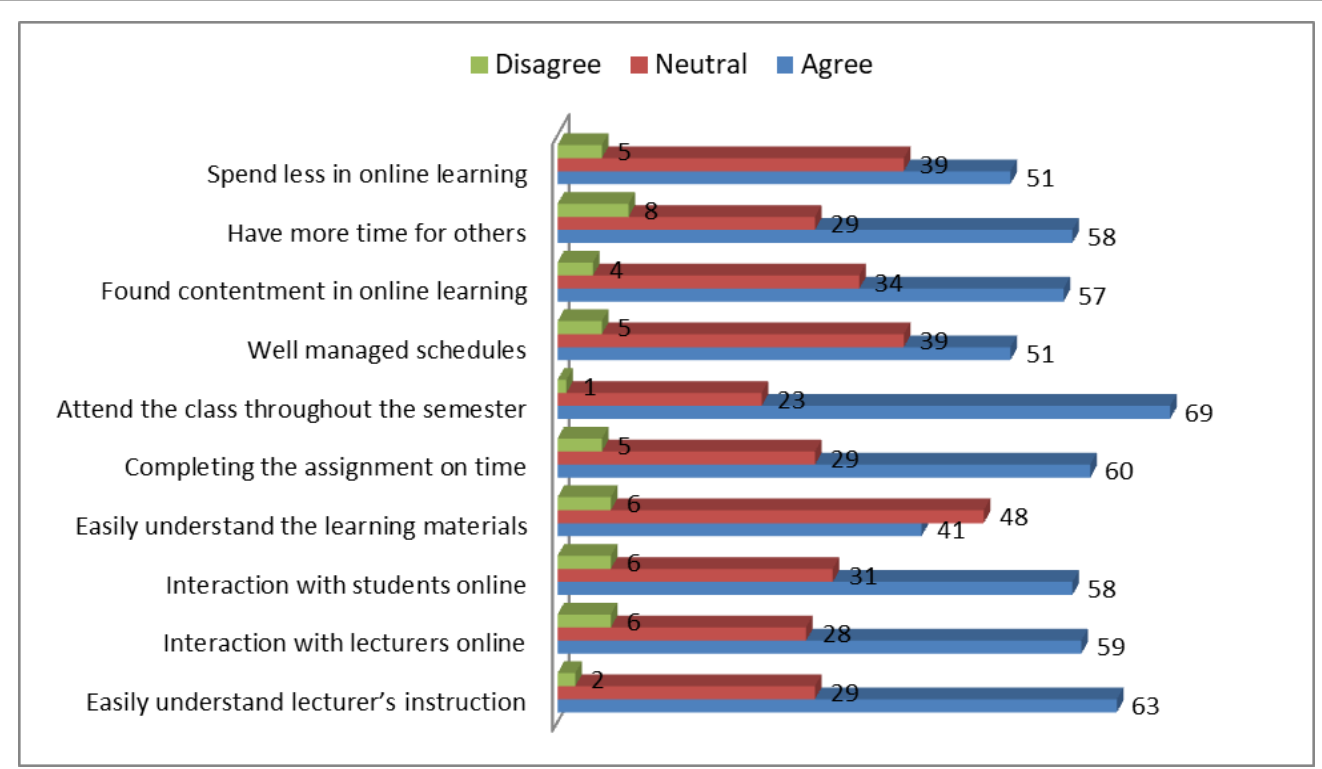

Figure 2. Learning experience

Some of the reinforcing factors are reflected in the easier way for students to understand the instructions given in face-to-face learning. Although most of the students spend less expenditure in online learning, only 69 (72\%) students attended all the class throughout the seemester. In addition, 58 (61\%) students had more time to do other activities. Concerning the materials, only $48(43 \%)$ of students were easily understand the learning materials in live conferences.

\subsection{Learning Medium and Material Format}

The application platform used for learning English at Al-Azhar University and North Sumatra University from mid-March 2020 to August 2021 used various media and formats as presented in the following figures:

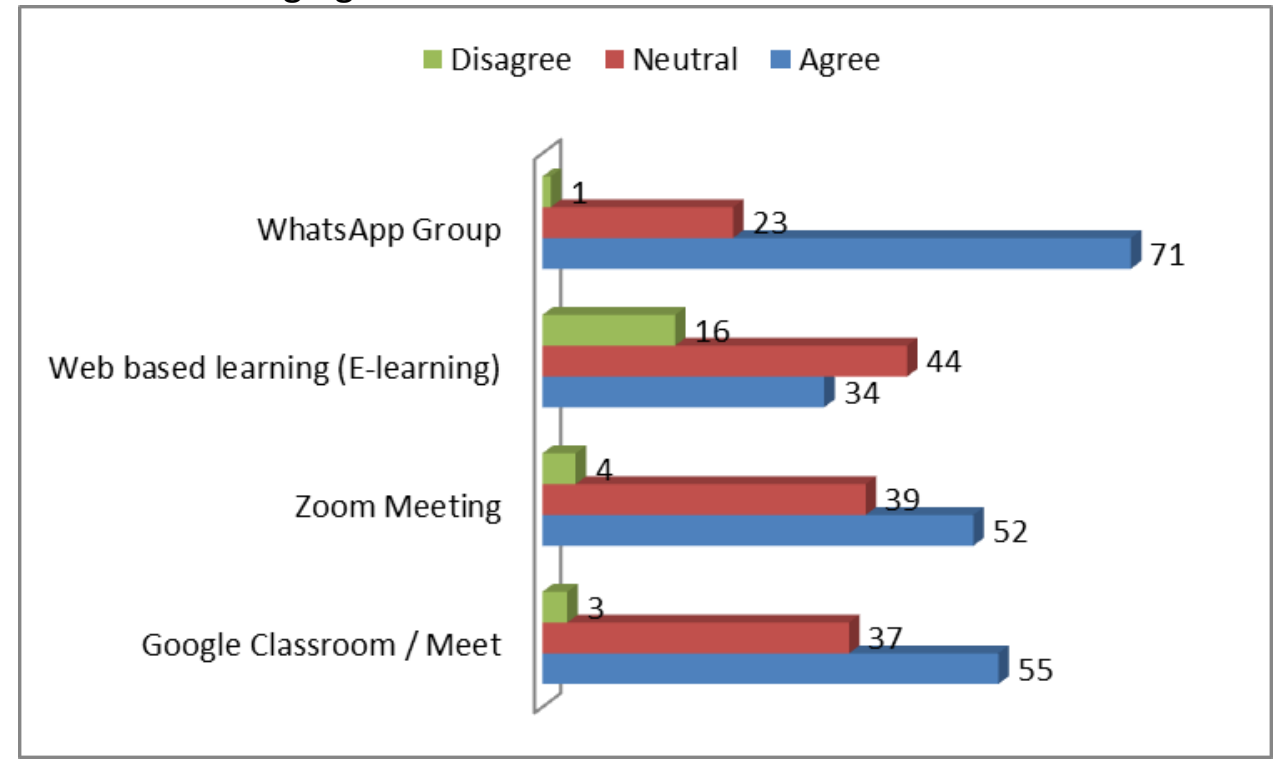

Figure 3. Preferred online learning medium

Indeed, at the beginning of the pandemic, the change in the learning system required an adaptation for both lecturers and students. Among the difficulties face by students and lecturers are the using of the media/platforms, changes in learning methods, tools and 
facilities that did not meet the requirements, and limited mastery of technology. Lecturers have started to learn, adapt, and innovate in creating effective learning media and techniques during the pandemic. Mixed learning are also in demand by lecturers and students, because the offline class will fill the gap of online presence. The learning media most widely used by students and lecturers is Google Classroom/Meet. Students feel the ease of using Google Classroom/meet because they can access and work on questions or assignments through their respective devices on time.

The effectiveness of using Google Classroom is the easeness in using this media, namely the ease of downloading files from student work and providing grades to students. In addition, the time limit can be set in collecting assignments that save much of lecturers' time. For students, it is a way to practice self-managing time. Another online learning medium that is also often used by students and lecturers is Zoom Meeting. This learning media that provides a virtual meeting facility between students and lecturers is classified as very helpful in the implementation of online learning. The lecturer uses Zoom as a means to present material directly to students. Students also feel the ease of using Zoom because they can ask questions directly or write messages to lecturers during live session lectures through the chat menu that has been provided by Zoom. In addition, online learning through live sessions can also be recorded and sent to the e-mail addresses of lecturers and students.

Both universities also provide web based E-learning. Students and lecturer expected the E-Learning portals to accomodate the online learning activities. But this platform needs more preparation and improvement. Both students and lecturers complain that Web based learning (E-Learning) is often inaccessible or under maintenance. In line with (Redaputri et al., 2021), the effectiveness of online learning is underlying on the preparedness of institution.

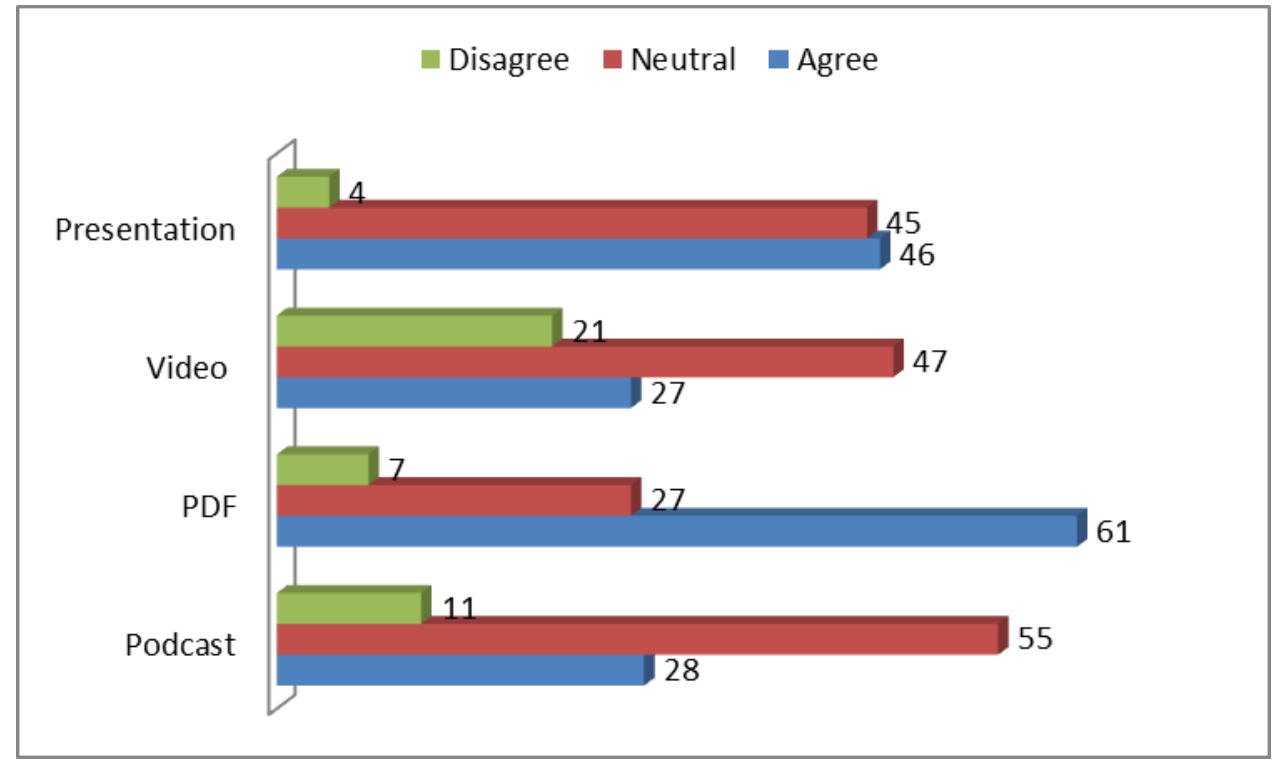

Figure 4. Preferred material formats

Other medium used for online learning are audio media and podcasts. The use of this media is limited to voice but can be used as an effective learning alternative in delivering learning instructions when the lecturer is not available to face to face online, for example when the lecturer is unable to attend. This learning media only takes place in one direction. Students listen to material from audio media or podcasts. This learning media is used quite 
often, it's just that its use is limited to certain materials related to the listening aspect, for example, to learn pronunciation.

Based on the results of the study, it can be concluded that the learning media used by lecturers and students to carry out online learning. There are learning media that are proven to be effective to use so that they are in demand by lecturers and students, for example, WhatsApp Groups, Google Classroom/Meet, and Zoom Meetings. Meanwhile, learning media that are less attractive to lecturers and students are E-Learning, audio media, and podcasts. Each learning media has its own advantages and disadvantages. The best way to increase student interest is to use media that are most suitable for learning objectives. For example, podcast media is very suitable to be used in learning topics related to pronunciation. The video format is focused on visuals, while the pdf document format is for reading.

\subsection{Advantages and Limitiation of Online Learning}

Carrying out the online learning courses encountered various obstacles. These obstacles are divided into two main obstacles, namely the students' problems while attending the online learning process, and comprehension of learning materials. The following table will present obstacles experienced by students and lecturers in the implementation of online learning.

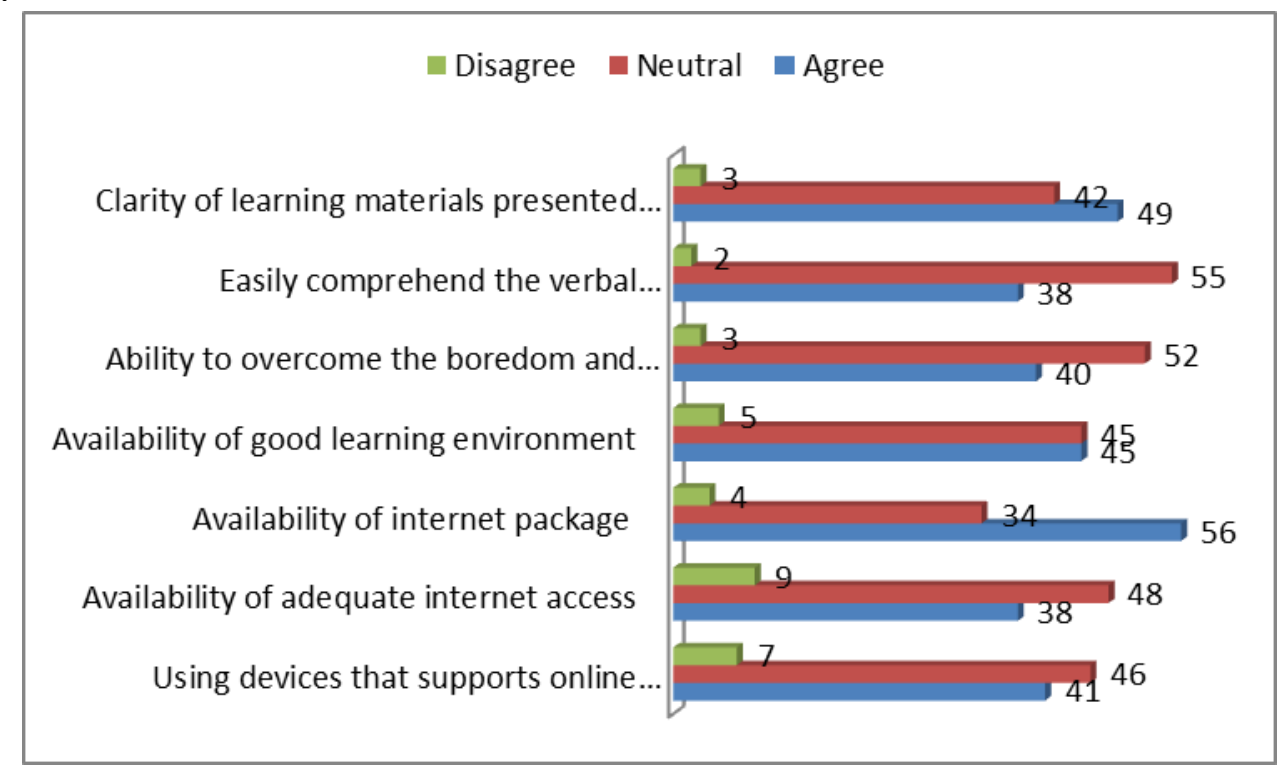

Figure 5. Learning devices, environment and material comprehension

The advantages and limitations of online learning are identified based on students' preferences on the learning devices, environment, and material comprehension. Students used the adequate devices to attend the online learning. Out of 95 students, $38(40 \%)$ of students admitted that they had a the adequate internet access to participate in online learning. Most of students live in remote area where the stable internet access was not available in their areas.

The combination of supporting devices and internet access is a key factor in online learning implementation. This affects the quality of verbal teaching carried out by lecturers. Similar to internet access result, it is found that $40 \%$ of students can easily understand the instructions when the lecturer teaches verbally. It shows that the quality of audio and video 
in online learning through zoom and google meet is the key students comprehension on material presented verbally.

Another obstacle faced by students is related to the availability of resources to buy internet packages. Out of 95 students, $35,8 \%$ of students experiences the unadequate internet packages. In addition, 4 students admitted that they had limited resources to pay for the internet package for online learning. Students who live in distances with difficult internet access generally experience it. The more difficult it is to find an adequate internet network, the greater the costs that should be borne. However, the government has provided assistance to help smooth online learning by providing internet packages for students. However, this is not a solution for students living in rural areas, where only $2 \mathrm{G}$ and $3 \mathrm{G}$ internet networks are available, while $4 \mathrm{G}$ is needed for meeting. This is affirmed by (Cahyadi et al., 2021), that the students in Indonesia face challenging to meet their online learning requirements such as the limited-capacity mobile networks. To overcome this obstacle, lecturers prepare learning instructional materials in the form of podcasts instead of videos and use pdf documents that may be accessed anytime with a limited internet network.

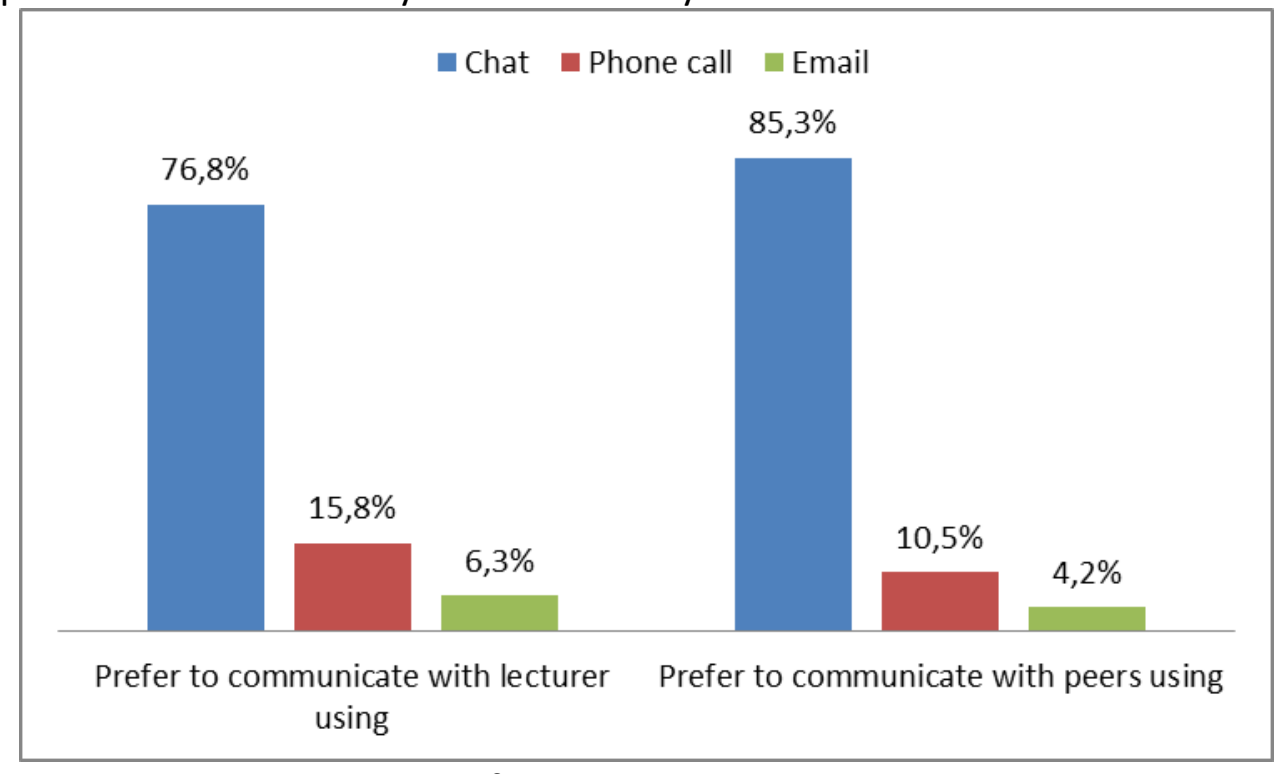

Figure 6. Preferred communication medium

In terms of communicating, as shown in Figure 6, chat applications such as WhatsApp Groups are the most frequently used online learning media by students and lecturers in communicating. Phone calls has second place as a medium of communication between students and lecturers. It is align with the finding of (Lemay et al., 2021), students who are missing to contact with peers and lecturer use technology to keep contact.

WhatsApp Groups have proven to be the most widely used communication media between students and lecturers, or between students and their colleagues because it functions as a communication medium, a means of information, and a medium for sharing document files of learning materials, while email is usually used to send the task files.

\section{Conclusion}

Based on the findings above, this study summarizes several conclusions, namely (1) students prefer the implementation of online learning; (2) online learning media that are proven to be effective for use and interest by students, namely WhatsApp Groups, Google Classroom, Zoom/Google Meet; (3) the main obstacle in learning is an unstable signal. These 
obstacles resulted in some students not being able to attend lectures via Zoom/Google Meet. The lecturer should provide recordings for those who did not attend the live session lectures. Another obstacle is also in understanding the material taught online. This understanding seems to lie in the willingness of students to take part in live learning sessions or to do independent learning after class activities. However, another aspect that should be taken into consideration is the effectiveness of lecturers in using media and presenting online learning materials.

Students are increasingly comfortable with online learning. As long as students have devices and internet connections, students can access information from anywhere, anytime. Online learning is saving cost. There are no more travel and accommodation costs. Students from out of town can continue to be with their families and study from home without incurring the high cost of renting housing around campuses in the city.

Although online learning may be convenient and flexible, it requires user independence. It will not be easy for all students to be comfortable with self-study. Some want to participate in face-to-face discussions. Users also need constructive feedback which can be very effective, but if it is not provided properly or on time it will reduce the students' satisfaction. No matter how hard the lecturer and students engaged in communication to online platforms, nothing can replace human contact. Constant stay in front of a screen can result in physical complaints such as causing poor eyesight, strain injuries, and other physical problems. Lecturers need to divide learning sessions and provide time for students to relax before moving on to the next session. It helps lecturers and students to obtain the energy needed to continue the class. Online learning requires self-discipline. If students lack selfdiscipline, they are less likely to be motivated to self-study. Face to face learning have the benefit of tracking progress and lags easily. In online learning, there is always a risk that students will just study the material without paying attention.

\section{Acknowledgements}

The authors were supported by the research grant from Ministry of Research, Technology and Higher Education of Republic Indonesia, for funding period 2021.

\section{References}

Arifin, T. S. ., Natassa, N., Khoirunnisa, D., \& Hendrowati, R. (2021). The Level of Student Satisfaction with the Online Learning Process During a Pandemic Using the K-means Algorithm. Inform : Jurnal IImiah Bidang Teknologi Informasi Dan Komunikasi, 6(2), 123-126. https://doi.org/10.25139/INFORM.V6I2.3945

Atqia, W., Hendrawanto, Y., \& Alimatussa'diyah, A. (2021). PERSEPSI DOSEN DAN MAHASISWA TERHADAP PEMBELAJARAN DARING BAHASA INDONESIA PADA MASA PANDEMI COVID 19. INDONESIA: Jurnal Pembelajaran Bahasa Dan Sastra Indonesia, 2(2), 92-105. https://doi.org/10.26858/INDONESIA.V2I2.22289

Bani Hani, A., Hijazein, Y., Hadadin, H., Jarkas, A. K., Al-Tamimi, Z., Amarin, M., Shatarat, A., Abu Abeeleh, M., \& Al-Taher, R. (2021). E-Learning during COVID-19 pandemic; Turning a crisis into opportunity: A cross-sectional study at The University of Jordan. Annals of Medicine and Surgery, 70, 102882. https://doi.org/10.1016/J.AMSU.2021.102882

Barteit, S., Guzek, D., Jahn, A., Bärnighausen, T., Jorge, M. M., \& Neuhann, F. (2020). Evaluation of e-learning for medical education in low- and middle-income countries: A systematic review. Computers \& Education, 145. 
Students' Preferences on Online Learning in The New Normal Period of The Covid-19 Pandemic, Roswani Siregar, Syahron Lubis, Risnawaty, Andri Ramadhan

https://doi.org/10.1016/J.COMPEDU.2019.103726

Cahyadi, A., Hendryadi, Widyastuti, S., Mufidah, V. N., \& Achmadi. (2021). Emergency remote teaching evaluation of the higher education in Indonesia. Heliyon, 7(8). https://doi.org/10.1016/J.HELIYON.2021.E07788

Churiyah, M., Sholikhan, Filianti, \& Sakdiyyah, D. A. (2020). Indonesia Education Readiness Conducting Distance Learning in Covid-19 Pandemic Situation. International Journal of Multicultural and Multireligious Understanding, 7(6), 491-507. https://doi.org/10.18415/IJMMU.V716.1833

Elzainy, A., El Sadik, A., \& Al Abdulmonem, W. (2020). Experience of e-learning and online assessment during the COVID-19 pandemic at the College of Medicine, Qassim University. Journal of Taibah University Medical Sciences, 15(6), 456-462. https://doi.org/10.1016/J.JTUMED.2020.09.005

Hamid, R., Sentryo, I., \& Hasan, S. (2020). Online learning and its problems in the Covid-19 emergency period. Jurnal Prima Edukasia, 8(1), 86-95. https://doi.org/10.21831/JPE.V8I1.32165

Hutauruk, A., \& Sidabutar, R. (2020). Kendala Pembelajaran Daring Selama Masa Pandemi di Kalangan Mahasiswa Pendidikan Matematika: Kajian Kualiatatif Deskriptif. Sepren, 2(1), 45-45. https://doi.org/10.36655/SEPREN.V2I1.364

Lemay, D. J., Bazelais, P., \& Doleck, T. (2021). Transition to online learning during the COVID19 pandemic. Computers in Human Behavior Reports, 4, 100130. https://doi.org/10.1016/J.CHBR.2021.100130

Mulyono, H., Suryoputro, G., \& Jamil, S. R. (2021). The application of WhatsApp to support online learning during the COVID-19 pandemic in Indonesia. Heliyon, 7(8), e07853. https://doi.org/10.1016/J.HELIYON.2021.E07853

Muthuprasad, T., Aiswarya, S., Aditya, K. S., \& Jha, G. K. (2021). Students' perception and preference for online education in India during COVID -19 pandemic. Social Sciences \& Humanities Open, 3(1), 100101. https://doi.org/10.1016/J.SSAHO.2020.100101

Redaputri, A. P., Dwi Prastyo, Y., Yusuf, M., \& Barusman, S. (2021). Analisis Kepuasan Mahasiswa dalam Pelaksanaan Pembelajaran Online di Era Pandemi Covid-19. Lectura: Jurnal Pendidikan, 12(1), 1-14. https://doi.org/10.31849/LECTURA.V12I1.5463

Rizaldi, D. R., \& Fatimah, Z. (2020). How the Distance Learning can be a Solution during the Covid-19 Pandemic. International Journal of Asian Education, 1(3), 117-124. https://doi.org/10.46966/IJAE.V113.42

Sadikin, A., \& Hamidah, A. (2020). Pembelajaran Daring di Tengah Wabah Covid-19. BIODIK, 6(2), 214-224. https://doi.org/10.22437/BIO.V6I2.9759

Syahruddin, S., Mohd Yaakob, M. F., Rasyad, A., Widodo, A. W., Sukendro, S., Suwardi, S., Lani, A., Sari, L. P., Mansur, M., Razali, R., \& Syam, A. (2021). Students' acceptance to distance learning during Covid-19: the role of geographical areas among Indonesian sports science Heliyon, 7(9), e08043. https://doi.org/10.1016/J.HELIYON.2021.E08043/ATTACHMENT/1A091540-1F9F4987-9D8C-6538B8A3FA1C/MMC1

Thepwongsa, I., Sripa, P., Muthukumar, R., Jenwitheesuk, K., Virasiri, S., \& Nonjui, P. (2021). The effects of a newly established online learning management system: the perspectives of Thai medical students in a public medical school. Heliyon, 7(10), e08182. https://doi.org/10.1016/J.HELIYON.2021.E08182

Utami, A. U. (2021). Tingkat Kepuasan Mahasiswa Pada Pembelajaran Daring Mata Kuliah 
Fisika Dasar. Jurnal Kiprah, 9(1), 23-29. https://doi.org/10.31629/KIPRAH.V9I1.3219

Violante, M. G., \& Vezzetti, E. (2015). Virtual interactive e-learning application: An evaluation of the student satisfaction. Computer Applications in Engineering Education, 23(1), 72-91. https://doi.org/10.1002/CAE.21580 
Students' Preferences on Online Learning in The New Normal Period of The Covid-19 Pandemic, Roswani Siregar, Syahron Lubis, Risnawaty, Andri Ramadhan

\section{Appendix}

\begin{tabular}{|c|c|c|c|c|c|c|c|c|c|}
\hline \multirow[b]{2}{*}{ No } & \multirow{2}{*}{ Questions } & \multicolumn{6}{|c|}{ Responses } & \multirow{2}{*}{$\begin{array}{c}\text { Total } \\
\text { Respon- } \\
\text { ded }\end{array}$} & \multirow{2}{*}{$\begin{array}{l}\text { Unres- } \\
\text { ponded }\end{array}$} \\
\hline & & $A$ & $\%$ & $\mathrm{~N}$ & $\%$ & $\mathrm{D}$ & $\%$ & & \\
\hline$A$ & Learning Activities & & & & & & & & \\
\hline 1 & $\begin{array}{l}\text { Easily understand lecturer's } \\
\text { instruction }\end{array}$ & 63 & $66,3 \%$ & 29 & $30,5 \%$ & 2 & $2,1 \%$ & 94 & 1 \\
\hline 2 & Interaction with lecturers online & 59 & $62,1 \%$ & 28 & $29,5 \%$ & 6 & $6,3 \%$ & 93 & 2 \\
\hline 3 & Interaction with students online & 58 & $61,1 \%$ & 31 & $32,6 \%$ & 6 & $6,3 \%$ & 95 & 0 \\
\hline 4 & $\begin{array}{l}\text { Easily understand the learning } \\
\text { materials }\end{array}$ & 41 & $43,2 \%$ & 48 & $50,5 \%$ & 6 & $6,3 \%$ & 95 & 0 \\
\hline 5 & $\begin{array}{l}\text { Completing the assignment on } \\
\text { time }\end{array}$ & 60 & $63,2 \%$ & 29 & $30,5 \%$ & 5 & $5,3 \%$ & 94 & 1 \\
\hline B & $\begin{array}{l}\text { Time Management and } \\
\text { Attendance }\end{array}$ & & & & & & & & \\
\hline 6 & $\begin{array}{l}\text { Attend the class throughout the } \\
\text { semester }\end{array}$ & 69 & $72,6 \%$ & 23 & $24,2 \%$ & 1 & $1,1 \%$ & 93 & 2 \\
\hline 7 & Well managed schedules & 51 & $53,7 \%$ & 39 & $41,1 \%$ & 5 & $5,3 \%$ & 95 & 0 \\
\hline C & Interest and Resources & & & & & & & & \\
\hline 8 & $\begin{array}{l}\text { Found contentment in online } \\
\text { learning }\end{array}$ & 57 & $60,0 \%$ & 34 & $35,8 \%$ & 4 & $4,2 \%$ & 95 & 0 \\
\hline 9 & Have more time for others & 58 & $61,1 \%$ & 29 & $30,5 \%$ & 8 & $8,4 \%$ & 95 & 0 \\
\hline \multirow[t]{2}{*}{10} & Spend less in online learning & 51 & $53,7 \%$ & 39 & $41,1 \%$ & 5 & $5,3 \%$ & 95 & 0 \\
\hline & Choice & $1^{*}$ & & $2 *$ & & $3^{*}$ & & & \\
\hline 11 & $\begin{array}{l}\text { The learning system mostly } \\
\text { needed today }\end{array}$ & 37 & $38,9 \%$ & 25 & $26,3 \%$ & 33 & $34,7 \%$ & 95 & 0 \\
\hline & \multicolumn{9}{|c|}{ Desription: $A=$ Agree; $N=$ Neutral; $D=$ Disagree } \\
\hline & \multicolumn{9}{|c|}{$1=$ Face to face $; 2=$ Online learning; $3=$ Blended Learning } \\
\hline & $\mathrm{N}=95$ & & & & & & & & \\
\hline
\end{tabular}

Table 1. Student Preferences for Online Learning

\begin{tabular}{|c|c|c|c|c|c|c|c|c|c|}
\hline \multirow{2}{*}{ No } & \multirow{2}{*}{ Questions } & \multicolumn{6}{|c|}{ Responses } & \multirow{2}{*}{$\begin{array}{c}\text { Total } \\
\text { Respon-ded }\end{array}$} & \multirow{2}{*}{$\begin{array}{l}\text { Unres- } \\
\text { ponded }\end{array}$} \\
\hline & & A & $\%$ & $\mathrm{~N}$ & $\%$ & $\mathrm{D}$ & $\%$ & & \\
\hline$A$ & Learning medium & & & & & & & & \\
\hline 1 & Google Classroom / Meet & 55 & $57,9 \%$ & 37 & $38,9 \%$ & 3 & $3,2 \%$ & 95 & 0 \\
\hline 2 & Zoom Meeting & 52 & $54,7 \%$ & 39 & $41,1 \%$ & 4 & $4,2 \%$ & 95 & 0 \\
\hline 3 & Web based learning (E-learning) & 34 & $35,8 \%$ & 44 & $46,3 \%$ & 16 & $16,8 \%$ & 94 & 1 \\
\hline 4 & WhatsApp Group & 71 & $74,7 \%$ & 23 & $24,2 \%$ & 1 & $1,1 \%$ & 95 & 0 \\
\hline B & Material format & & & & & & & & \\
\hline 5 & Podcast & 28 & $29,5 \%$ & 55 & $57,9 \%$ & 11 & $11,6 \%$ & 94 & 1 \\
\hline 6 & PDF & 61 & $64,2 \%$ & 27 & $28,4 \%$ & 7 & $7,4 \%$ & 95 & 0 \\
\hline 7 & Video & 27 & $28,4 \%$ & 47 & $49,5 \%$ & 21 & $22,1 \%$ & 95 & 0 \\
\hline 8 & Presentation & 46 & $48,4 \%$ & 45 & $47,4 \%$ & 4 & $4,2 \%$ & 95 & 0 \\
\hline \multicolumn{10}{|c|}{ Desription: $A=$ Agree; $N=$ Neutral; $D=$ Disagree } \\
\hline & $N=95$ & & & & & & & & \\
\hline
\end{tabular}

Table 2. Preferred Learning Medium and Material Formats

\begin{tabular}{|c|c|c|c|c|c|c|c|c|c|}
\hline \multirow[b]{2}{*}{ No } & \multirow[b]{2}{*}{ Questions } & \multicolumn{6}{|c|}{ Responses } & \multirow{2}{*}{$\begin{array}{c}\text { Total } \\
\text { Respon- } \\
\text { ded }\end{array}$} & \multirow{2}{*}{$\begin{array}{l}\text { Unres- } \\
\text { ponded }\end{array}$} \\
\hline & & A & $\%$ & $\mathrm{~N}$ & $\%$ & $\mathrm{D}$ & $\%$ & & \\
\hline A & Devices and learning environment & & & & & & & & \\
\hline 1 & $\begin{array}{l}\text { Using devices that supports online } \\
\text { learning }\end{array}$ & 41 & $43,2 \%$ & 46 & $48,4 \%$ & 7 & $7,4 \%$ & 94 & 1 \\
\hline
\end{tabular}




\begin{tabular}{|c|c|c|c|c|c|c|c|c|c|}
\hline 2 & $\begin{array}{l}\text { Availability of adequate internet } \\
\text { access }\end{array}$ & 38 & $40,0 \%$ & 48 & $50,5 \%$ & 9 & $9,5 \%$ & 95 & 0 \\
\hline 3 & Availability of internet package & 56 & $58,9 \%$ & 34 & $35,8 \%$ & 4 & $4,2 \%$ & 94 & 1 \\
\hline 4 & $\begin{array}{l}\text { Availability of good learning } \\
\text { environment }\end{array}$ & 45 & $47,4 \%$ & 45 & $47,4 \%$ & 5 & $5,3 \%$ & 95 & 0 \\
\hline 5 & $\begin{array}{l}\text { Ability to overcome the boredom } \\
\text { and fatigue after online learning }\end{array}$ & 40 & $42,1 \%$ & 52 & $54,7 \%$ & 3 & $3,2 \%$ & 95 & 0 \\
\hline B & $\begin{array}{l}\text { Comprehension on learning } \\
\text { materials }\end{array}$ & & & & & & & & \\
\hline 6 & $\begin{array}{l}\text { Easily comprehend the verbal } \\
\text { instruction of the lecturer }\end{array}$ & 38 & $40,0 \%$ & 55 & $57,9 \%$ & 2 & $2,1 \%$ & 95 & 1 \\
\hline 7 & $\begin{array}{l}\text { Clarity of learning materials } \\
\text { presented in the form of documents, } \\
\text { videos, and podcasts }\end{array}$ & 49 & $51,6 \%$ & 42 & $44,2 \%$ & 3 & $3,2 \%$ & 94 & 1 \\
\hline C & Communication medium & $\mathrm{C}$ & & $\mathrm{T}$ & & E & & & \\
\hline 8 & $\begin{array}{l}\text { Prefer to communicate with lecturer } \\
\text { using... }\end{array}$ & 73 & $76,8 \%$ & 15 & $15,8 \%$ & 6 & $6,3 \%$ & 94 & 1 \\
\hline 9 & $\begin{array}{l}\text { Prefer to communicate with peers } \\
\text { using }\end{array}$ & 81 & $85,3 \%$ & 10 & $10,5 \%$ & 4 & $4,2 \%$ & 95 & 0 \\
\hline & \multicolumn{9}{|c|}{ Desription: $A=$ Agree; $N=$ Neutral; $D=$ Disagree } \\
\hline & \multicolumn{9}{|l|}{$\mathrm{C}=$ Chat $; \mathrm{T}=$ Phpne call; $\mathrm{E}=$ Email } \\
\hline & $N=95$ & & & & & & & & \\
\hline
\end{tabular}

Table 3. Advantages and Limitations of Online Learning 